\title{
AMS DATING OF HUMAN BONE FROM PALAU: NEW EVIDENCE FOR A PRE-2000 BP SETTLEMENT
}

\author{
Scott M Fitzpatrick \\ Department of Anthropology, University of Oregon, Eugene, Oregon 97403, USA. Email: malthus@ darkwing.uoregon.edu.
}

ABSTRACT. Direct dating of a human bone fragment from the Chelechol ra Orrak site (western Micronesia) has yielded one of the earliest dates for Palau thus far. This date compares well with recently collected paleoenvironmental evidence and radiocarbon dates on Babeldaob Island suggesting that settlement of the Palauan archipelago took place much earlier than previously thought.

\section{INTRODUCTION}

The first human settlement of islands in western Micronesia (including the Marianas, Yap, and Palau; Figure 1) has been debated for decades. Archaeological evidence from Tarague Beach on Guam (Kurashina and Clayshulte 1983; Kurashina et al. 1984) and Achugao Point on Saipan (Butler 1994) in the Marianas demonstrate that people settled the northern part of this region by at least the late second millennium $\mathrm{BC}$. This is corroborated by more recent paleoenvironmental research from the Orote Peninsula in Guam (Athens and Ward 1995).

Until recently, it was unclear when the settlement of Yap and Palau occurred. Prior to 1998, the earliest dates were approximately 2000 BP. A wealth of archaeological information derived from cultural resource management projects on Koror and the large volcanic island of Babeldaob now suggests that settlement took place closer to 2500 BP (Beardsley 1998; Liston et al. 1998a, 1998b, 1998c; Reith and Liston 2001; Wickler et al. 1998), and according to paleoenvironmental evidence, perhaps even as early as 4500 BP (Athens and Ward 1999; Dodson and Intoh 1999).

Osborne (1979) thought that if the Marianas were settled from some part of southeast Asia, then Yap and Palau might have been stepping stones to the northern reaches of western Micronesia. Alternatively, Tsang (1992) and Starosta (1995) propose a colonization of the Marianas by peoples from Taiwan, though some linguists argue that Chamorro speakers have more immediate links to the Philippines (Reid 1998). Recent genetic evidence indicates the Marianas and Yap were probably settled independently from Island Southeast Asia, possibly the Philippines, and that gene flow may have also occurred from central-eastern Micronesia (Lum and Cann 2000:165). Palau appears to have genetic contributions from southeast Asia, central-eastern Micronesia, and New Guinea, a reflection of its geographical proximity to all three regions (Lum and Cann 2000:166). Despite the complex settlement pattern that has emerged in western Micronesia, involving genetically distinct populations from various regions, it appears likely that Yap and Palau have a greater human antiquity than the archaeological record indicates, perhaps contemporaneous with that of the Marianas.

This paper reports one of the oldest known dates in Palau associated with cultural material and the oldest human skeleton recorded for the Palau and Yap Islands. Excavations in summer 2000 at the Chelechol ra Orrak site by archaeologists from the University of Oregon and Palau Division of Cultural Affairs uncovered human burials beneath architectural features related to Yapese stone money quarrying (tentatively dated to within the last 400-500 years; Fitzpatrick 2000, 2001, 2002). Accelerator mass spectrometry radiocarbon (AMS ${ }^{14} \mathrm{C}$ ) dating of human bone in burials located beneath this quarry activity, however, places human presence much earlier. 


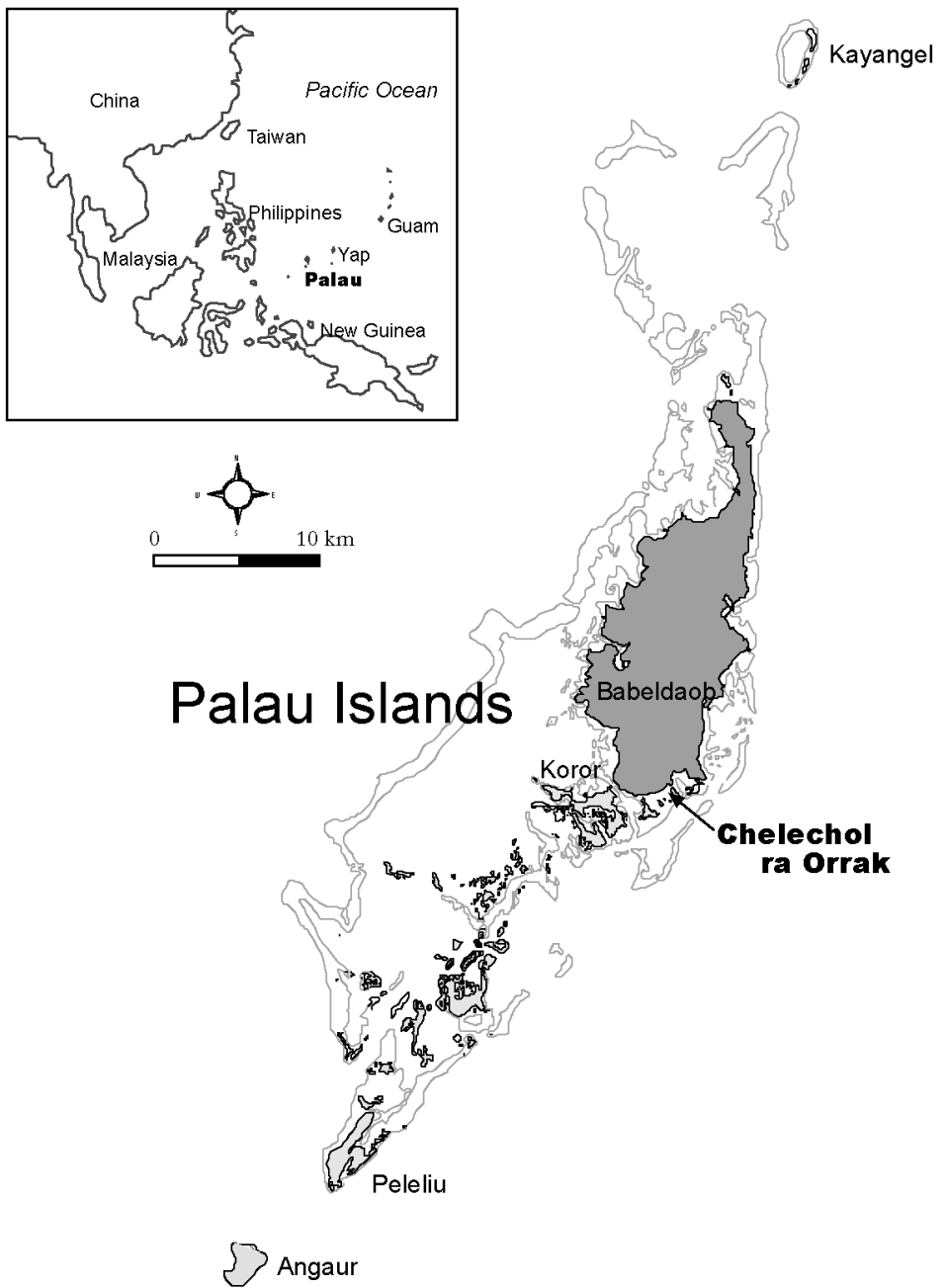

Figure 1 Map of western Micronesia

\section{BACKGROUND}

Chelechol ra Orrak ("beach of Orrak") lies along the southern fringe of Orrak Island just $1 \mathrm{~km}$ east of southern Airai State on the larger volcanic island of Babeldaob. Two unfinished stone money disks-architectural features including rock mounds, walls, docks, and alignments, and oral traditions (Fitzpatrick, unpublished manuscript; Rita Olsudong, personal communication 1998) -attest to its use as a locale for quarrying stone money. Prior to this research, however, it was unknown whether earlier cultural deposits were present.

Cultural material recovered during excavations at the site included stone, shell, and bone tools, a large faunal assemblage, limestone debitage, and charcoal. Also recorded at the site were at least 25 human burials found in sandy deposits from 50-100 centimeters below surface (cmbs). Test Units 1 
and 4 accounted for most of the skeletal material and 14 of the individuals (Nelson, unpublished report). To determine the age of the burials, a human cranial bone fragment from Test Unit 1, where at least six adults were present, was submitted for AMS ${ }^{14} \mathrm{C}$ dating.

\section{METHODS}

The human bone fragment was AMS dated at the University of Arizona and calibrated using CALIB 4.3 after Stuiver et al. (1998) ${ }^{1}$. The bone sample was first demineralized in $0.6 \mathrm{M} \mathrm{HCl}$ with heat, rinsed to a neutral $\mathrm{pH}$, and the remaining liquid evaporated. The sample was then put back into solution with dilute ammonium hydroxide, run through a cation exchange resin, and freeze-dried to recover bone collagen. The collagen was then combusted under vacuum and the resulting gas converted to graphite for AMS analysis.

\section{RESULTS AND DISCUSSION}

The date obtained from the human cranial bone fragment was $2680 \pm 40 \mathrm{BP}$ and calibrated to produce a date of cal BC 890 (830) $800(1 \sigma)$. Because the prehistoric diet is not clear, the sample was also calibrated as 50\% marine and 50\% terrestrial (Stuiver et al. 1998) to better reflect a mixed diet of shellfish, fish, and aroids common to the region (see Keegan and DeNiro 1988; McGovern-Wilson and Quinn 1996; Weisler 2000:118 for other similar applications). This adjusts the date to BC $770(750) 550(1 \sigma)$, making the age only $120-250$ years younger.

This is the earliest date associated with cultural material in Palau outside of Babeldaob Island, the oldest skeleton recorded for Palau and Yap, and precedes other known Rock Island settlements by over 1000 years (Masse 1989). Although additional dates are needed to determine the exact chronology of the burials, it is possible this site represents one of the initial settlement populations to the archipelago. Prior to 1998 only three other samples yielded dates earlier than 2000 BP. These were subsequently discarded by Masse (1990:219-20) as pre-cultural shell (Masse 1990), a fossil beach shell deposit (Masse 1989; Takayama 1979), and not interpretable (an unidentified seed or nut collected by Osborne during his 1968-1969 survey [Masse 1990]). Disregarding these early dates, Masse (1990:220) advocated a "[B]elauan cultural chronology [that] appears to begin not much earlier than A.D. 0." He supports his conclusion by stating that the majority of ${ }^{14} \mathrm{C}$ dates fit into a chronology within the last two millennia and that Takayama's (1979) suggestion of sea-level rise "cannot explain away the lack of early archaeological materials by presuming their submergence" (Masse 1990:216). Masse (1990:220) goes on to say, however, that the "prehistoric sequence is admittedly 'rock island-centric' and is sure to be modified as further archaeological work is conducted."

The early date from Orrak Island, four others from Omis Cave ranging from 2100 to 2400 BP (Fitzpatrick 2001 and manuscript in review), and a host of other dates collected on Babeldaob in the range of 2500-3500 BP during the last several years (Welch 2000) may lend support to Osborne's (1979) assertion that Palau was a "stepping" stone into the Pacific and makes it likely that earlier dates will be found on both volcanic and limestone islands in the Palauan archipelago.

\section{ARCHAEOLOGICAL SAMPLE}

AA-40957. Chelechol ra Orrak

$2680 \pm 40$

$\delta^{13} \mathrm{C}=-15.7 \%$

\footnotetext{
${ }^{1} \mathrm{~A}$ local $\Delta \mathrm{R}$ for Palau has not yet been determined, so the mean global reservoir correction was used (Stuiver et al. 1998). See Phelan (1999) and Guilderson et al. (2000) for recent attempts to determine $\Delta$ R correction values in other parts of the Pacific.
} 
This determination was obtained from a human cranial bone fragment $(3 \mathrm{~g})$ recovered from Test Unit 1, Layer 9, at a depth of 90-100 cmbs. Calibrated date ranges at $1 \sigma$ : BC 890-800 and BC 770550 (50\% marine and 50\% terrestrial). Calibrated date range at $2 \sigma: \mathrm{BC} 900-800$ and $\mathrm{BC} 790-500$ (50\% marine and $50 \%$ terrestrial).

\section{ACKNOWLEDGMENTS}

This research was supported by a National Science Foundation dissertation research improvement grant (BCS-0001531) and a University of Oregon-Palau Division of Cultural Affairs cooperative archaeological field training project funded by the Sasakawa Foundation. I thank the Division of Cultural Affairs for their continued encouragement and support over the years. Greg Nelson (University of Oregon) analyzed the skeletal material and aided in selecting samples for dating. Jon Erlandson, Torben Rick, and William Ayres gave valuable advice about specimen selection and commented on previous drafts of this paper. I also thank all of the University of Oregon students who helped with site survey, excavation, and laboratory work at Chelchol ra Orrak and the editors of the journal for help in preparing this manuscript.

\section{REFERENCES}

Athens JS, Ward JV. 1995. Paleoenvironment of the Orote Peninsula, Guam. Micronesica 28:205-23.

Athens JS, Ward JV. 1999. Archaeological data recovery for the compact road, Babeldaob Island, Republic of Palau. Historic preservation investigations phase II. Volume IV: The holocene paleoenvironment of Palau. International Archaeological Research Institute, Inc.

Beardsley FR. 1998. Sngall Ridge, Belau: Burials, spirit walks, and painted pottery. Paper presented at the 16th Congress of the Indo-Pacific Prehistory Association, Melaka, Malaysia, 1-7 July 1998.

Butler BM. 1994. Early prehistoric settlement in the Marianas Islands: new evidence from Saipan. Man and Culture in Oceania 10:15-38.

Dodson J, Intoh M. 1999. Prehistory and paleoecology of Yap, Federated States of Micronesia. Quaternary International 59:17-26.

Fitzpatrick SM. 2000. Archaeological survey of a Yapese stone money quarry on Orrak Island. Unpublished manuscript.

Fitzpatrick SM 2001. Archaeological investigation of Omis Cave: a Yapese stone money quarry in Palau. Archaeology in Oceania 36:153-62.

Fitzpatrick SM. 2002. A radiocarbon chronology of Yapese stone money quarries in Palau. Micronesica. Forthcoming.

Guilderson TP, Schrag DP, Goddard E, Kashgarian M, Wellington GM, Linsley BK. 2000. Southwest subtropical Pacific surface water radiocarbon in a highresolution coral record. Radiocarbon 42(2):249-56.

Keegan WF, De Niro MJ. 1988. Stable carbon- and nitrogen-isotope ratios of bone collagen used to study coral-reef and terrestrial components of pre-historic Bahamian diet. American Antiquity 53:320-36.

Kurashina H, Clayshulte RN. 1983. Site formation processes and cultural sequence at Tarague, Guam. Bulle- tin of the Indo-Pacific Prehistory Association 4:11422.

Kurashina H, Moore D, Kataoka O, Clayshulte R, Ray E. 1984. Prehistoric and protohistoric cultural occurrences at Tarague, Guam. Asian Perspectives 24:5768.

Liston J, Kaschko MW, Welch DJ. 1998a. Archaeological inventory survey for the capital relocation project, Melekeok, Republic of Palau. Honolulu: International Archaeological Research Institute.

Liston J, Tuggle HD, Mangieri TM, Kaschko MW, Desilets M. 1998b. Archaeological data recovery for the compact road, Babeldaob Island, Republic of Palau. Historic preservation investigations phase II. Volume I: Fieldwork reports. Honolulu: International Archaeological Research Institute.

Liston J, Mangieri TM, Grant D, Kaschko MW, Tuggle HD. 1998c. Archaeological data recovery for the compact road, Babeldaob Island, Republic of Palau. Historic preservation investigations phase II. Volume II: Fieldwork reports. Honolulu: International Archaeological Research Institute.

Lum JK, Cann RL. 2000. MtDNA lineage analysis: Origins and migrations of Micronesians and Polynesians. American Journal of Physical Anthropology 113:15168.

Masse B. 1989. The archaeology and ecology of fishing in the Belau Islands, Micronesia [unpublished $\mathrm{PhD}$ dissertation]. Ann Arbor: University Microfilms and University of Southern Illinois, Carbondale.

Masse B. 1990. Radiocarbon dating, sea level change and the peopling of Palau. Micronesica Supplement 2: 213-30.

McGovern-Wilson R, Quinn C. 1996. Stable isotope analysis of ten individuals from Afetna, Saipan, Northern Mariana Islands. Journal of Archaeological 
Science 23:59-65.

Nelson G. Human skeletal remains from site B:IR-1:23, Orrak Island, Palau. Preliminary report in possession of author. Unpublished.

Osborne D. 1979. Archaeological test excavations in the Palau Islands, 1968-69. Micronesica Supplement 1.

Phelan MB. 1999. A $\Delta$ R correction value for Samoa from known-age marine shells. Radiocarbon 41(1):99-101.

Reid L. 1998. Morphosyntactic evidence for the position of Chamorro in the Austronesian language family. Paper presented at the 16th congress of the Indo-Pacific Prehistory Association, Melaka, Malaysia, 1-7 July 1998.

Reith TM, Liston J. 2001. Archaeological data recovery at Ngermereues Ridge, Ngesaol, Koror, Republic of Palau. Honolulu: International Archaeological Research Institute.

Starosta S. 1995. A grammatical subgrouping of Formosan languages. In: Li P, Tsang CH, Huang YK, Ho DA, Tseng CY, editors. Austronesian studies relating to Taiwan. Taipei: Academia Sinica. p 683-726.

Stuiver M, Reimer PJ, Bard E, Beck JW, Burr GS, Hughen KA, Kromer B, McCormac G, van der Plicht J, Spurk M. 1998. INTCAL98 radiocarbon age calibration, 24,000-0 BP. Radiocarbon 40(3):1041-83.
Takayama J. 1979. Archaeological investigations of PAAT-2 in the Palaus: an interim report. In: Kusakabe $\mathrm{H}$, editor. Cultural anthropological research on the folkculture in the Western Caroline Islands of Micronesia in 1977. Tokyo: Committee for Micronesian Research, Tokyo University of Foreign Studies. p 81103.

Tsang CH. 1992. Archaeology of the P'eng-Hu Islands. Institute of History and Philology Special Publication 95. Taipei: Academia Sinica.

Weisler MI. 2000. Burial artifacts from the Marshall Islands: description, dating, and evidence for extra-archipelago contacts. Micronesica 33(1/2):111-36.

Welch DJ. 2001. Early Upland expansion of Palauan settlement. In: Stevenson CM, Lee G, Morin FJ, editors. Pacific 2000-Proceedings of the 5th International Conference on Easter Island and the Pacific. Los Osos: Easter Island Foundation. p 179-84.

Wickler SK, Welch DJ, Tomonari-Tuggle MJ, Liston J, Tuggle HD. 1998. Intensive archaeological survey for the Palau compact road, Babeldaob Island, Palau. Historic preservation investigations phase I. Volume I. Scope, background, results, excavation, and recommendations. Honolulu: International Archaeological Research Institute. 